\title{
Applying Multi-media to Optimize English Teaching Context
}

\author{
Suirong Cao \\ College of Music, Jiangxi University of Technology
}

\begin{abstract}
Keywords: Multi-media; Context; Situational Context; Cultural Context; English Teaching
\end{abstract}
\begin{abstract}
In the classroom teaching, it is teacher-oriented and student-centered, and the teaching contents and the teaching tools are the intermediaries for the bilateral activities. The multi-media technology broadens the teaching resources and enriches the teaching means for the English class. The teacher simulates the real language environment by multi-media and creates the language atmosphere of English Learning under the appropriate circumstances. Only in this way can we really stimulate students' interest and potential in learning English, and thus effectively improve the students' comprehensive ability of language application. In English teaching, we must understand the context, use the context, optimize the teaching context by the multi-media, and make the context effectively serve our English teaching. Thus, it becomes a trend to research optimizing English teaching context through multi-media. In this paper, we introduce the main situation of current English teaching context and analyze the contents and characteristics of the junior middle school English teaching; we overview the origin of cultural context and situational context; we inquiry how to use multi-media to optimize the English teaching context in junior middle school, further analyze the effects of multi-media technology acted on the English teaching, and run a comparative analysis between the teaching effect and the traditional English classroom teaching.
\end{abstract}

\section{Introduction}

Along with the new curriculum reform, English teaching pays more and more attention to the cultivation of the students' communicative competence. In the teaching of English, language environment is very important to cultivate students' English ability and accomplish the communicative task. In the English classroom teaching, in order to cultivate students' communicative ability, we should create a good English communication environment for students to have a space to practice as far as possible and provide opportunities for language practice to let the students speaks more. Therefore, in English classroom teachers should strive to create scenarios related to students' real life, to combine students' physical and mental characteristics with the real life. And the teachers should create real context according to the requirements of the target level to let students experience life in the English classroom, to truly enhance students' English learning interest and improve the students' listening, speaking, reading, writing ability and comprehensive language application competence.

It is a revolution to apply multi-media to optimize Junior Middle School English teaching context. Applying multi-media technology in Junior English teaching enriches the students' learning life and the students' visual field. Advantages of multimedia application in English teaching are as following:

(1) Wide variety of forms of expression for modern media. It can present the information of text, images, sound, video and flash, and create an illustrated, vivid and relaxed teaching situation, 
(2) Strong interactivity. Multi-media information is a hypertext structure. Overcoming the shortcomings of the traditional linear structure, it is conducive to cultivating students' divergent thinking and improving the students' learning enthusiasm; the multi-sensory stimulation brought by multimedia can fully mobilize the initiative of learning and establish a teaching mode truly based on learning, which is conducive to the cultivation of students' creative thinking ability.

(3) Breaking through the boundaries of information dissemination. Multimedia greatly enrich and improve the teaching content, open the teaching field and extend the time of student learning and communication between teachers and students. Providing more extensive learning approaches, it creates the conditions for the socialization and life-long learning of education.

It is based on the advantages multimedia in English teaching can optimize teaching context that students can be in the midst of a real language environment and feel the language stimulation on full ranges. It also can make the English teaching situation-oriented and the language learning communication-oriented, so that students can master linguistic knowledge and cultivate the language competence in a relaxed and pleasant atmosphere. Therefore, multimedia plays an indispensable role in English teaching.

Taking English teaching in Junior High School grade one as an example, this paper analyzes how to optimize the context of the classroom teaching through the multi-media.

\section{Analysis on the Main Features of English Teaching in Junior One}

With the development of the curriculum reform of primary education, the new edition of National Standards for English Curriculum has new features. Taking the "New target English Go for It" as an example, the whole book adopts a compilation mode of task chain. Taking the topic as the main line, the grammar and function as a supplement, this book presents grammar knowledge structure orderly and emphasizes the authenticity and diversity of teaching contents and activities.

Emphasizing the Integration of Language and Culture. The content of English teaching determines the its characteristics, so cultivating students' awareness of cultural fusion is the inevitable requirement to achieve the aim of English teaching in the middle school. The teachers should focus on activating the students' existed cultural background knowledge, cultivate the sensitivity of the differences between Chinese and Western cultures and blend political education into the language teaching. The characteristic of language is the practicality and intercommunication, and it needs a lot of practice to master the knowledge and form the language ability. (1) The study of English language is closely related to the culture of English-speaking countries, therefore, teachers need to select the cultural contents associated to students' life as much as possible and create a good cultural atmosphere. For example: Unit Six in the "New Target English" of grade seven, "Do you like bananas?" is a topic about food, so during the preparation, the teacher should prepare some knowledge about the cultural differences between Chinese and Western to make the students recognize the influence of western fast food on the health. It is the fundamental purpose to cultivate students' communicative ability in the English teaching. The teachers should let the students participate in the discussion of which is the health food and which is the harmful food, let students take part in the communication and blend into the cultural scene.

Ighlighting the Students Autonomy, Respecting Individual Differences. The New English Curriculum Standards for Basic Education in China clearly points out: This course of English curriculum reform advocates the learning methods of experiencing, practicing, participating, cooperating and communicating and task-based teaching approaches ". The teacher becomes the 
foster, the guide and the partner of students' learning ability, and all the teaching activities emphasize on student centered. In the teaching activity, the teacher should let each student actively participate in the curriculum and have the opportunity of practice speaking, and improve each student's ability to use language.

In the English teaching in Junior High School grade one, it is mainly to feel, understand, and use language in the audio-visual perception, performance and games, and in the activities that create leisure and pleasure in the form of cooperating with students. Teachers should create context teaching in the classroom let the students involved in this language scene, and further master the language in the course contents. By doing this, it activates the learning atmosphere in classroom and provides a broad space for the students' creative thinking. It also let students experience the success of joy, and thus to stimulate interest in learning.

Emphasizing on Developing the Learning Strategies. English teaching should focus on the cultivation of students' learning ability, letting the learners learn to study. The New Curriculum Standards requires that the teachers should not only pay attention to cultivating the students' language ability, but also should attach importance to cultivating students' other abilities in the teaching process. These capabilities include: autonomous learning ability, cooperative learning ability and communicative ability. Learning to study is the basis of the students' lifelong sustainable learning and development. Just as the proverb "it's better to teach fishing than to offer fish." So in English teaching, it's better to teach students good learning method and cultivate good English learning habits than to impart knowledge into students. Under the new curriculum reform, English teaching should guide the students to actively transfer the culture backgrounds of English-speaking countries based on psychological quality of English culture learning, and grasp the sense of English which namely is the learning habits of sound, form and meaning in the English learning. And good English learning habits are usually the results of the accumulation of bit by bit, which build a solid foundation for developing the habit of independent thinking as well as the learning and development in the future.

\section{The Theoretical Analysis of English Teaching Context in Junior Middle School}

"Application of context" can provide students with scenes that are direct and close to students' life, which makes it easier for students to enter the specific atmosphere of language and arouse the students' interest and enthusiasm for learning, so as to better understand and master the language. The significance of applying context in English teaching:

(1) Providing real, perceived cultural background and life scenes. It can place the students in the real context and make them know something about British and American culture and customs. It will effectively guide them to make a proper cultural evaluation and analysis, and make a reasonable choice of different cultures. Students are exposed to different culture and background, and thus it will broaden their own personal view and horizon of knowledge.

(2) Letting the students understand the knowledge of cultural background. It will make the contents such as the vocabulary and grammar in the textbook easier to understand by integrating the real scenes of life into teaching, and it is also easier to understand for students. It can encourage students to talk and discuss, make the students feel the expressive effects of the target language, and also raise students' sensitivity to the target language.

(3) Be conducive to developing students' understanding ability. The original context can give students provide linguistic context and enable the students to fully understand features and 
application effects of the target language, which can make the students explore and analyze the significance of the passage from different aspects, so as to improve the students' comprehensive understanding ability. In the English teaching, the vocabulary, sentences, semantics and text are all progressive and the difficulty is from easy to difficult, but they are indeed consistent. Therefore, the context in reading is particularly important.

(4) Be conducive to cultivating students' comprehensive ability. In the English teaching, it will help students improve their communicative level and cultivate students' appreciation ability and imagination if the teachers are conscious to create a language learning environment for students. It can make students form thinking habits of the target language unconsciously and bring up their interest of learning language by creating linguistic context in the class, which not only reflected in verbal communication but also embodied in the accumulation and precipitation of culture.

(5) Improving students' enthusiasm of learning language. The use of context in the teaching can make the students exposure to feeling the target language and maximally attract their enthusiasm of learning language. Teachers let the students have an intuitive and perceptual cognition through displaying pictures by the multi-media, which will greatly improve students' interest in learning and enhance their sense of participation when they contact with the familiar scenes and similar life experiences, thus to learn language better.

\section{The Construction and Optimization of Multimedia Language Context}

The term Duo Mei Ti is the Chinese translation of MULTIMEDIA, there are many definition of multimedia. From the narrow perspective of English teaching, it refers to Integrated Learning Systems (ILSS) which is controlled by computer. As a matter of fact, connotation and scope of the technology of multimedia in the English teaching has gone beyond the word: MULTIMEDIA, it is the combination of hypertext information and multimedia technology in the essence, i.e. the HYPER - MEDIA SYSTEMS. Hyper-media system a huge interactive database comprehensive used by a kind of nonlinear multimedia information, which includes text file, static image, real-time film and processing system. In the past, the emphasis in English teaching is a kind of static context, the context, while the multimedia brings us a dynamic context. With the advent of the information age, modern multimedia technology provides very convenient conditions for teaching English to create related context. The direction to the study of context has gone to simulate true context which provides a new perspective for the study of dynamic context. The contents of pronunciation, vocabulary, reading and so on in the teaching of English are all involved in the interaction between teachers and students. The application of multimedia technology makes all aspects of English teaching to be buckled closely, which has brought great convenience to both teachers and students. Along with the widespread application of multimedia in teaching, each link of teaching are closely related to the context.

Using multimedia to present is more vivid, concrete and convenient. From the physiological view, teacher's behavior such as self-confidence, excitement, surprise, admiration and so on will have a great impact on the activities of nerve cells of students' two cerebral hemispheres. In the multimedia classroom, the teacher teaches according to the pre-designed teaching courseware, the students follow steps of teachers to learn the contents. Stimulating the visual and auditory senses in a full range through the teacher's explanation and the courseware's images, animation and video, the students communicates with the teacher according to their own needs. 
In English class, the specific teaching context will directly affect the students' comprehension of the English text. English classroom itself is a special scene of teaching. In order to help students to learn, it is necessary for English teachers to create teaching context according to the requirements of teaching, which is conducive to improving teaching efficiency and students' learning efficiency. The method of creating teaching context in English classroom is diverse.

\section{The Construction and Optimization of "Situational Context" in English Teaching}

With the extensive application of multimedia in the educational field, it has brought a new environment and a new cognitive way for students. Multimedia become the main body of information processing because of its flexible and diverse forms of expression and the characteristics of nonlinearity, interactivity and etc. It is in line with the cognitive psychology of students and is conducive to the active construction of the knowledge's meaning for students. The successful classroom teaching is premised on the construction of good situational contexts, namely to provide the real or simulated situational context which is related to the basic contents of learners or familiar with students' life. The construction of situational context in the classroom involves the elements of communicative intention, discourse range, the tone of speech, and the way of discourse and so on, and the method of construction is diverse.

Communication intention is the core of the dialogue meaning, combining with the dialogue scope, dialogue way and the tone of the dialogue to constitute the whole dialogue. The dialogue scope refers to the specific environment of language occurrence, including the time, place, person, event, etc. In the whole teaching activity the content is fixed, but the teaching method is flexible. How to construct the teaching activity in classroom can affect the students' engagement and the teaching results. In the construction of the topic range, in order to let the students be interested in the curriculum content, the teacher needs to build a wonderful introduction in the classroom teaching to attract the students' attention. The construction of the tone of the dialogue is mainly around the factors of emotion, status, etc. In the teaching, the teachers apply the verbal and non-verbal methods to construct an equal and democratic atmosphere and to make the teacher-student relationship harmonious, which is conducive to the smooth progress of situational teaching. The way of language includes the teacher's spoken language and the text of the multimedia courseware. The multimedia presents the teaching contents to the students vividly. Only by combining the teacher's spoken language and the text of courseware can it constructs the classroom context which can resonate with the students.

\section{The Construction and Optimization of "Cultural Context" in English Teaching}

Language is the carrier of culture and culture is the humanistic environment in which language exists, so it is necessary to understand the culture that the language depends on if you want to know a language truly. Language is a symbol which is the symbol of people's cognition, thinking, expression and communication, and it is involved in the specific process of culture formation. The language that people understands is built on the basis of their own ethnic customs and cultural background, and people are always used to explaining and understanding other people's language according to their own cultural background and linguistic habits. Therefore, in the process of teaching, the purpose that teachers should create a context for students is to let students better to learn English language and culture. The teachers transmit the information of images, animation and so on to make the students 
perceive the information of cultural atmosphere which is different from their own ethnic culture, only by this can the students learn and use language better.

Students learning language is to communicate, and communication is link up the emotion of thought and culture. The fundamental purpose of creating contexts lies in cultivating students' language ability of comprehensive application, and the teachers also should take the students' individual differences and cognitive ability into consideration in the process of teaching design. Therefore, in order to let students to understand the English language and culture better, we should create a natural and pleasant language environment for students, and let students perceive the English language and culture atmosphere which differs from their own nations by transmitting images, animation and other information with multimedia. Only in this way can we learn and use language better. Grade one is the introductory stage of English learning, the teachers should take advantage of the cyclic convenience of multimedia technology to show the differences between British and American culture and Chinese culture to let the students feel western culture in the cultural context constructed by the multimedia. And the teachers should make the students fully engaged in the real language environment and understand the western culture to lay the foundation for the future study. Such teaching method not only reflects the superiority of the multimedia teaching, arouses students' interest in learning, but also fully embodies the teaching idea of " emphasizing both teaching and learning"..

The pictures, audio and animation provided by multimedia is a kind of indirect context, although is not real context, it is the simulation context that is the most conducive to the teaching in addition to the direct context. In the simulation context, the teachers present different teaching contents in different stages. Therefore, in the process of English teaching, we should not only pay attention to situational context but also emphasize the creation of the cultural context according to the requirements of class. Nowadays, a qualified English teacher not only needs to have a strong English skills, but also needs a wealth of cultural knowledge to guide students to understand the social and cultural knowledge of British and American countries. Only in this way can the British and American culture be appropriately applied to English teaching in classroom. The students' full range of sensory stimulation of the application of multimedia can deepen the impression of the cultural knowledge of Thanksgiving Day. Teachers using the multimedia player to make the students learn the origin of the Thanksgiving Day culture and make the students feel the language culture in a certain language environment. If talk about Christmas in "Thanksgiving Day", the effect will be certainly different, so in the classroom not only needs to play the English flash related to the teaching contents, but also needs the psychological state of a fit time. Only in this way can we catch students' attention and stimulate students' rich imagination to really understand the cultural connotation contained in the festival. Only in this way can students accumulate rich cultural knowledge and can lay the foundation for mastering English.

\section{Conclusions}

With the development of information technology and the new requirements of English teaching put forward by the New Curriculum Standards, the use of multi-media in teaching is becoming more and more extensive. The use of multimedia technology has changed the traditional teaching means, enriched the teaching method, updated and perfected the teaching mode, improved the teaching efficiency and widened the students' knowledge. In the course of the study, we read a lot of literature, and fully realized the importance of context in English teaching process. The characteristics of the 
multi-media, such as the circulation, convenience and intuition, are fully embodied during the optimizing process of the English teaching context. This research put forward the proposal of how to optimize the English teaching context mainly based on the domestic existing research of language context and combined with our own practical experience. With the application of multimedia in the English teaching of first grade and taking it as an example, the teachers present the teaching contents through the means of sound, graphics, images, text, video and audio etc. This paper mainly explores how multi-media constructing and optimizing the English teaching context in English teaching. Mainly by combining theoretical analysis with case study of situational context and cultural context, this paper draws a conclusion that optimizing English teaching context by multimedia can improve the teaching results as well as enrich the students' horizon. Although this paper has some new ideas from the perspective of English teaching context, the exploration levels of this paper are superficial, and we need to explore how to optimize the English teaching context with multimedia more specifically.

\section{References}

[1] SHI Xiu-ju. A Study on the Appropriateness of Context and Speech [M]. Bei Jing: Language Press, 2004: 3 .

[2] QIU Hong. Good English Teaching Method [J]. Science Public (Science Education), 2010(10):43.

[3] CHANG Chen-guang, CHEN Yu-min. Functional Context Study [M]. Bei Jing: Foreign Language Teaching and Research Press, 2011:12.

[4] XIONG Xue-liang. Introduction to Cognitive Pragmatics [M]. Shang Hai: Shanghai Foreign Language Education Press, 1999:3.

[5] XIN Huan. The Application of the Modern Media in the Creation of English Teaching Scene [J]. Educational Technology and Equipment in China, 2008(1).

[6] GUO Ji-ling. A study of Context and Its Application in Translation [J]. Journal of Xinjiang Petroleum Education Institute, 2005(2).

[7] Ministry of Education: The Standard of English Curriculum for Senior Middle School of Full-time Compulsory Education (Experiment draft) [Z]. Bei Jing: Beijing Normal University Press.

[8] WANG Chu-ming. On the Context of Foreign Language Learning [D]. Guang Zhou: Guangdong University of Foreign Studies, 2007, 18.

[9] YOU Ze-qing. Grammar of Multimedia Language [J]. Information Technology Education, 2002(12).

[10] YOU Ze-qing. Research on the Cognitive Law of the Multimedia Picture Language [J]. Chinese Audio-visual Education, 2004(11). 